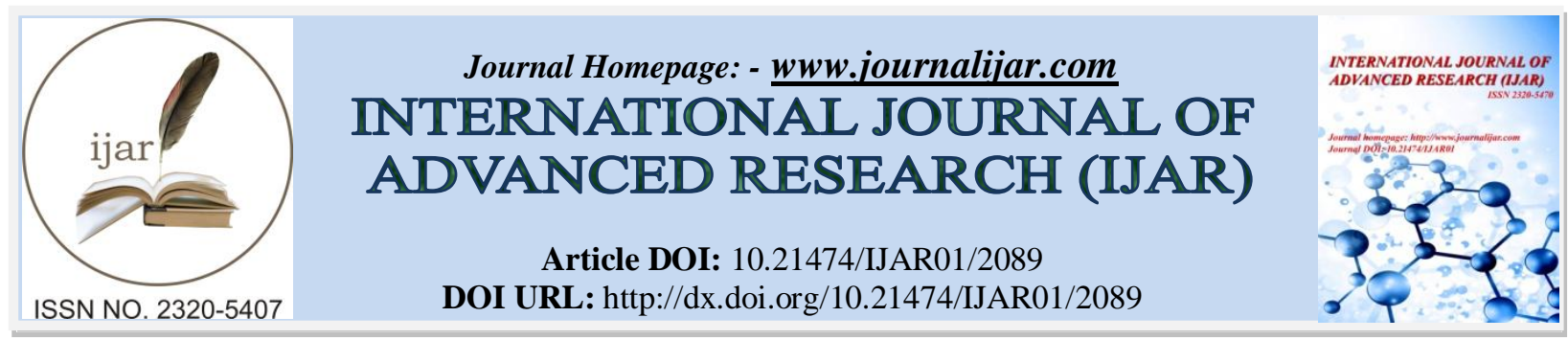

RESEARCH ARTICLE

\title{
EFFECT OF FRYING TIME AND TEMPERATURE ON CHARACTERISTICS OF CARROT (DAUCUS CAROTA, L.) CHIPS USING VACUUM FRYING.
}

Ismed.

Department of Agricultural Product Technology, Faculty of Agricultural Technology, Andalas University, Kampus Unand Limau Manis Padang, Indonesia-25163.

\section{Manuscript Info}

Manuscript History

Received: 24 September 2016

Final Accepted: 26 October 2016

Published: November 2016

Key words:-

carrot chips, vacuum frying, frying

temperature, frying time, characteristics

\begin{abstract}
This study investigated the effect of temperature and frying time on characteristics (crude fiber, vitamin $\mathrm{C}$, free fatty acid and total carotenoids content) of carrot chips using vacuum frying machine. The experiment was conducted in processing house of horticultural products at Nagari Batu Palano, Sungai Pua, Agam and Laboratory of Department of Agricultural Product Technology, Faculty of Agricultural Product Technology, Universitas Andalas, Padang from August to October 2015. This study used a completely randomized design (CRD) $3 \times 3$ factorial design. The first factor is frying temperature $\left(80^{\circ} \mathrm{C} / \mathrm{A} 1,85^{\circ} \mathrm{C} / \mathrm{A} 2,90^{\circ} \mathrm{C} / \mathrm{A} 3\right)$ and the second factor is frying time (50 minutes/B1, 60 minutes/B2, 70 minutes/B3). The results showed the optimum frying temperature is $90^{\circ} \mathrm{C}$ and optimum frying time is 50 minutes (A3B1 treatment) which a value of $15.66 \%$ crude fiber content, vitamin C $0.19 \%$, free fatty acid (FFA) $3.91 \%$ and total carotenoids $6485.50 \mathrm{mg} / 100 \mathrm{~g}$.
\end{abstract}

Copy Right, IJAR, 2016,. All rights reserved.

\section{Introduction:-}

Vegetables including foodstuffs which contain many nutrients and beneficial for humans. In addition, vegetables as a large of dietary fiber source for human body. Dietary fiber is useful for the smooth functioning of digestion and metabolism in the body ${ }^{1}$. Nowadays, the food consumption patterns are to produce a healthy and practical food product such as carrot chips. The carrots have the nutrients that the body needs, especially as a source of pro-vitamin A or $B$-carotene. The content of pro-vitamin A found in carrots is $12.000 \mathrm{IU}$ or $7125 \mu \mathrm{g}$ ( $1 \mathrm{IU}=0.6 \mu \mathrm{g} B$-carotene). Pro-vitamin A is a chemical compound forming vitamin A which is very necessary for vision, growth and development and maintaining epithelial tissue in a healthy state. The results showed that the nutrient deficiency is also related to the high morbidity and mortality, especially among children under five years old. Each year is estimated at more than 60,000 Indonesian children suffer from severe visual impairment level and a third of them became blind who could not be cured. This is because the consumption of vegetables is still low among carrots ${ }^{2}$.

Nowadays, vegetables consumed in the form of processed or cooked into various vegetables and consumed in the form of raw or fresh. The processing technology is required to maintain the availability and increase the domestic consumption of vegetables. One alternative is to do is process into chips vegetables ${ }^{1}$. According to ${ }^{3}$, the chips classified as types of food crackers, dry, and crispy. Chips are a kind of dry food that has long been known popular as a snack.

Corresponding Author:- Ismed.

Address:- Department of Agricultural Product Technology, Faculty of Agricultural Technology, Andalas University, Kampus Unand Limau Manis Padang, Indonesia-25163. 
The vacuum frying defined as the process of frying with pressures below atmospheric pressure, generally below 50 Torr $(6.65 \mathrm{kPa})$ due to the pressure drop in the boiling point of oil and materials ${ }^{4}$. The vacuum frying has several advantages, among others, can reduce the oil content in the product, to retain color and distinctive taste of the product due to the use of low temperature and low oxygen levels during the process, and have a negative impact less on the quality of oils ${ }^{5}$. Frying foods can change the pore structure of the products with the phenomenon of shrinkage or swelling ${ }^{6,7}$. The structural changes affecting the diffusivity of the gas and the liquid in the material ${ }^{8}$. Various approaches have been proposed to study the structural changes during drying. ${ }^{9}$ studied the drying potatoes and apples to take into account the shrinkage of the material and incorporate variable (term) rate on total water transfer equation by assuming an isothermal drying. ${ }^{10}$ studied the shrinking gel using gel gluten food starch modified Darcy's Law to calculate deformation fiscoelastis.

The changes that occur during frying is still difficult to model because of the many interrelated factors and should be taken into account, so it is necessary to identify structural changes during the frying in order to obtain better understand regarding the quality changes that occur. Porosity product formed during frying plays an important role in further oil absorption if crust begins to form on the surface of the product, for example there will be a pressure high enough then the product becomes fluffy. Our literature review showed frying models that have been developed so far have not shown a correlation between the raw material and the condition of the frying pan of volume change, such as shrinkage, porosity development and changes to the product. The purpose of this study was to investigate the effect of temperature and frying time on characteristics (crude fiber, vitamin $\mathrm{C}$, free fatty acid and total carotenoids content) of carrot chips using vacuum frying machine.

\section{Materials And Methods:-}

Materials:-

Carrot (Daucus carota, L.) variety Imperator was kindly provided by a local farmer in Batu Palano, Agam, West Sumatera-Indonesia, commercial palm oil, polipropilen, chemicals for analysis. The equipments used are vacuum frying machine water-jet type with $1.5 \mathrm{~kg}$ per batch (PT. Mesin Globalindo-Malang), spinner, hand sealer, and equipment for analysis.

\section{Sample preparation and frying conditions:-}

The carrots were washed, peeled, cut into slices (about $5 \mathrm{~mm}$ thickness). Banana slices were washed, drained and weighed before the frying. A vacuum fryer used vacuum frying machine water-jet type with $1.5 \mathrm{~kg}$ per batch (PT. Mesin Globalindo-Malang). A batch of $1.5 \mathrm{~kg}$ of carrot slices was placed in the vessel and fried in $12 \mathrm{~L}$ of palm oil under vacuum $(-60 \mathrm{cmHg})$. The treatments studied in this work were: (1) carrot chips were fried at three levels of frying temperature $\left(80^{\circ} \mathrm{C}, 85^{\circ} \mathrm{C}\right.$, and $\left.90^{\circ} \mathrm{C}\right)$, (2) various frying time $(50,60$, and 70 minutes). After vacuum frying, the fried carrot chips were to remove the frying oil used spiner ( \pm 5 minutes). Finally, a sample of fried carrot chips was packed in each polipropilen bag and carried to laboratory for analysis

\section{Methods:-}

This study used a completely randomized design (CRD) $3 \times 3$ factorial design. The first factor is frying temperature $\left(80^{\circ} \mathrm{C} / \mathrm{A} 1,85^{\circ} \mathrm{C} / \mathrm{A} 2\right.$, and $\left.90^{\circ} \mathrm{C} / \mathrm{A} 3\right)$ and the second factor is frying time $(50$ minutes/B1, 60 minutes/B2, and 70 minutes/B3). The treatments are A1B1 (T:80 ${ }^{\circ} \mathrm{C}, \mathrm{t}: 50 \mathrm{~min}$.), A1B2 (T:80 $\left.{ }^{\circ} \mathrm{C}, \mathrm{t}: 60 \mathrm{~min}.\right), \mathrm{A} 1 \mathrm{~B} 3$ (T:80 $\left.{ }^{\circ} \mathrm{C}, \mathrm{t}: 70 \mathrm{~min}.\right), \mathrm{A} 2 \mathrm{~B} 1$

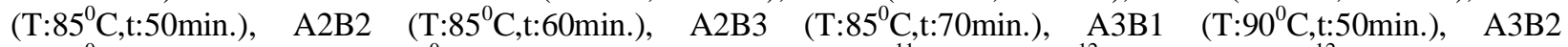
( T:90 ${ }^{0} \mathrm{C}, \mathrm{t}: 60 \mathrm{~min}$.), A3B3 (T:90 ${ }^{0} \mathrm{C}, \mathrm{t}: 70 \mathrm{~min}$.). Analysis crude fiber ${ }^{11}$, vitamin $\mathrm{C}^{12}$, free fatty acid ${ }^{12}$, total carotenoid

13. Statistics analysis used software SPSS 15.0. 


\section{Results And Discussion:- Crude Fiber Content:-}

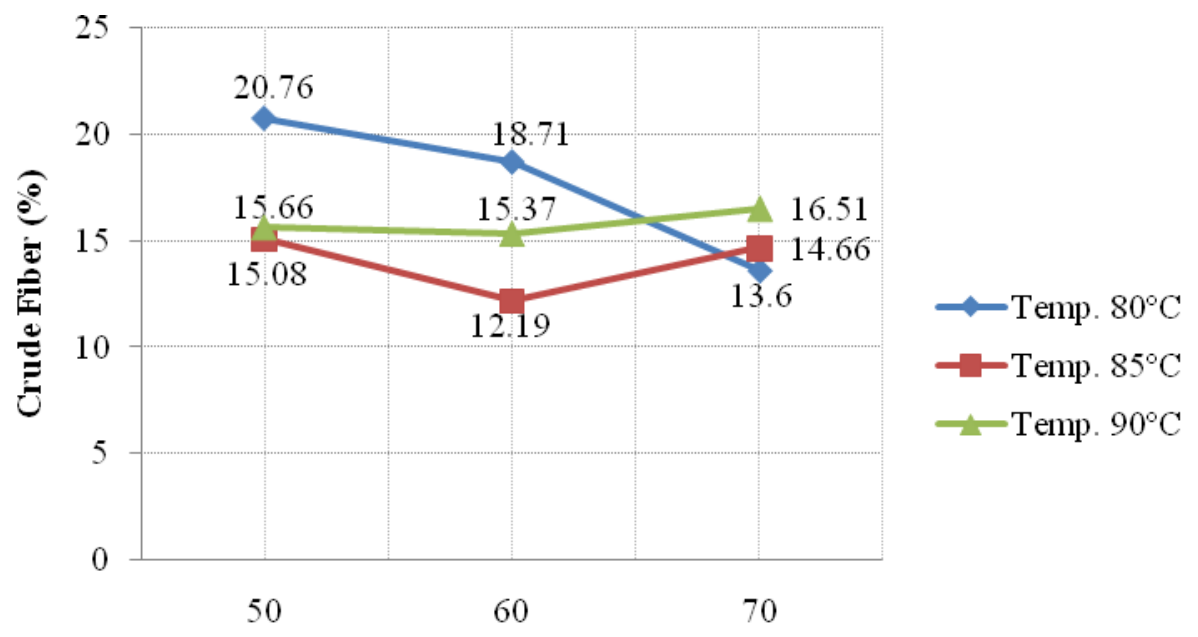

Frying Time (minutes)

Figure 1:- Effect of frying time and temperature on the crude fiber content of carrot chips

According to figure 1 , interaction of frying time and temperature showed significantly different $(\mathrm{P}<0.05)$ the crude fiber content of carrot chips. The treatment A1B1 (T: $80^{\circ} \mathrm{C}$, t: $50 \mathrm{~min}$.) had the highest crude fiber content that is $20.76 \%$, while treatment $\mathrm{A} 2 \mathrm{~B} 2\left(\mathrm{~T}: 85^{\circ} \mathrm{C}\right.$, t: $60 \mathrm{~min}$.) has the lowest crude fiber content that is $12.19 \%$. Dietary fiber is a component of plant tissue that is resistant to hydrolysis by enzymes in the stomach and small intestine. These fibers come from the cell walls of various vegetables and fruits. Chemically the cell wall consists of several types of carbohydrates such as cellulose, hemicellulose, pectin and lignin polymer noncarbohydrate-like, and mucilage. Therefore dietary fiber generally is carbohydrates or polysaccharides. Various types of plant foods generally contain a lot of dietary fiber. Approximately only about one-fifth to one-half of all crude fiber actually serves as dietary fiber. In the process of vacuum frying and cooking with low temperature heating, crude fiber content in carrot chips relative does not decline compared to the fresh ingredients ${ }^{14}$.

\section{Vitamin C:-}

Based on figure 2, interaction of frying time and temperature showed significantly different $(\mathrm{P}<0.05)$ the vitamin $\mathrm{C}$ content of carrot chips. The treatment A3B3 (T: $90^{\circ} \mathrm{C}, \mathrm{t}: 70 \mathrm{~min}$.) had the highest vitamin $\mathrm{C}$ content that is $0.33 \%$. Vitamin $\mathrm{C}$ content of carrot chips in figure 2 ranged from 0.13 to $0.33 \%$. This is due to differences in temperature and frying time resulted in differences in the vitamin $\mathrm{C}$ content of carrot chips are produced with vacuum frying.

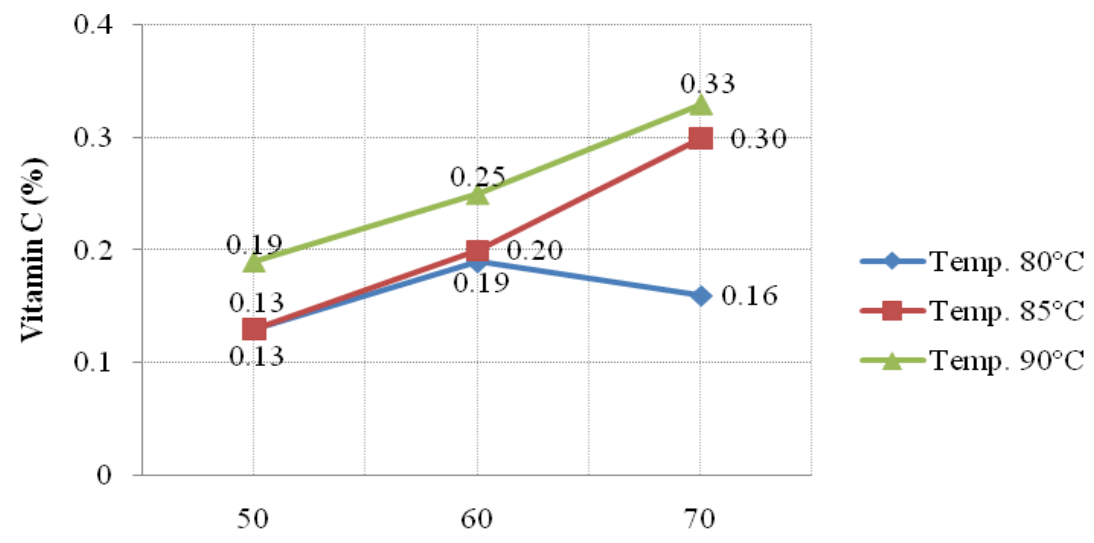

Frying Time (minutes)

Figure 2:- Effect of frying time and temperature on the vitamin $\mathrm{C}$ content of carrot chips 


\section{Free Fatty Acid content:-}

Figure 3 showed the interaction of frying time and temperature showed significantly different $(\mathrm{P}<0.05)$ the free fatty acid content of carrot chips. The treatment A3B3 $\left(\mathrm{T}: 90^{\circ} \mathrm{C}\right.$, t: $70 \mathrm{~min}$.) had the highest free fatty acid content that is $7.92 \%$, while treatment $\mathrm{A} 3 \mathrm{~B} 1\left(\mathrm{~T}: 90^{\circ} \mathrm{C}, \mathrm{t}: 50 \mathrm{~min}\right.$.) has the lowest free fatty acid content that is $3.91 \%$. The free fatty acid of carrot chips ranged from $3.91 \%$ to $7.92 \%$. It shows that most of the fatty acids content in carrots consisting of free fatty acids with a single bond. The rates of oxidation of the double bond run faster due to a chemical reaction and the carbon chain termination. This is consistent with research conducted ${ }^{15}$, which states that the stability of the oil depends on the number of double bonds. The more double bonds the lower oil stability. High content of fatty acids will cause rancidity which indicates that the product has been damaged.

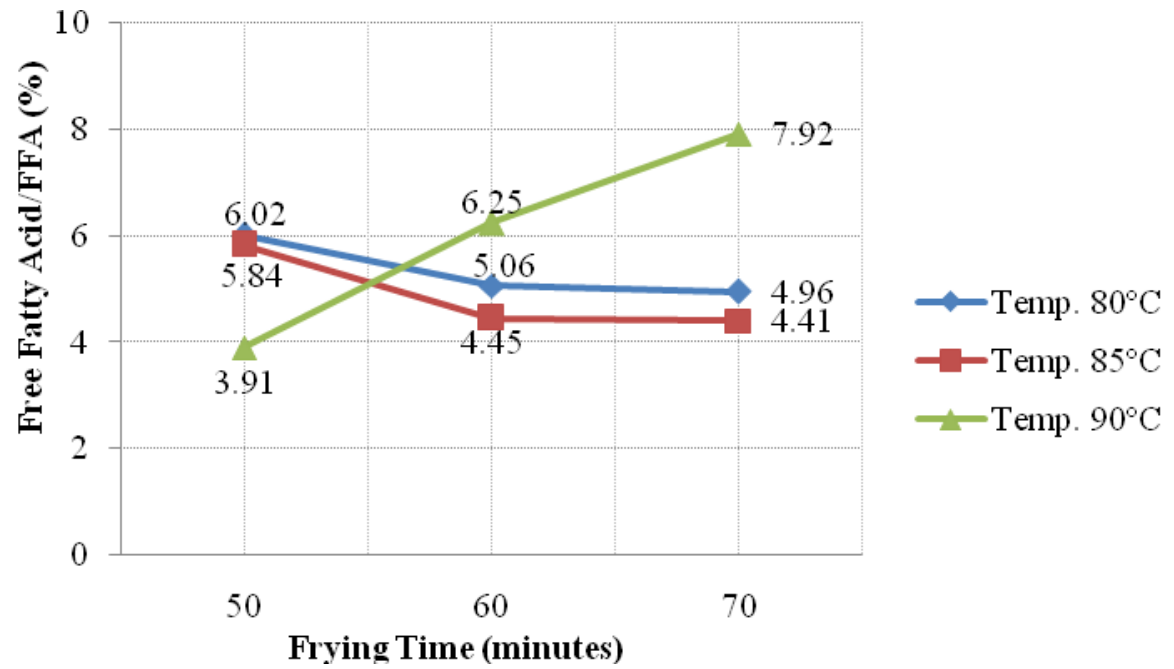

Figure 3:- Effect of frying time and temperature on the free fatty acid content of carrot chips

The free fatty acid content of carrot chips based on result still lower, it make carrot chips is not easy rancid and can have a long shelf durability. Therefore do not yet have SNI, free fatty acid carrot chips level can be compared with SNI chips tubers ${ }^{16}$. The average levels of total carotenoids and free fatty acids carrot chips using a combination treatment time and temperature vacuum frying. The content of free fatty acids is widely used by many food industry players as an indicator of oil damage. This method is a method of monitoring a relatively fast and reliable to measure the acidity of the oil during frying. Free fatty acid is mainly formed by hydrolysis of triglycerides and partly by the decomposition of hydroperoxide cooking oil at high temperatures in the presence of moisture and air. Free fatty acid formation is strongly associated with a smoke point, where increasing levels of free fatty acid lowering the smoke point ${ }^{17}$. Frying potatoes using palm oil proved that vacuum frying reduces formation of free fatty acid on palm oil as much as 2 times lower as the formation of free fatty acid to traditional frying pan. ${ }^{18}$ reported that vacuum frying process can reduce the oil content in sweet potato chips and chips beans respectively were 24 and $16 \%$ compared to the sweet potato chips and fried beans chips with traditional frying.

\section{Total carotenoid:-}

Based on figure 4, the total carotenoid of carrot chips ranged from $550.50-6485.50 \mathrm{mg} / 100 \mathrm{~g}$. The interaction of frying time and temperature showed significantly different $(\mathrm{P}<0.05)$ the total carotenoid content of carrot chips. The treatment A3B1 (T: $90^{\circ} \mathrm{C}, \mathrm{t}: 50 \mathrm{~min}$.) had the highest total carotenoid content that is $6485.50 \mathrm{mg} / 100 \mathrm{~g}$, while sample A3B3 (T: $90^{\circ} \mathrm{C}, \mathrm{t}: 70 \mathrm{~min}$.) has the lowest total carotenoid content that is $50.50 \mathrm{mg} / 100 \mathrm{~g}$. 


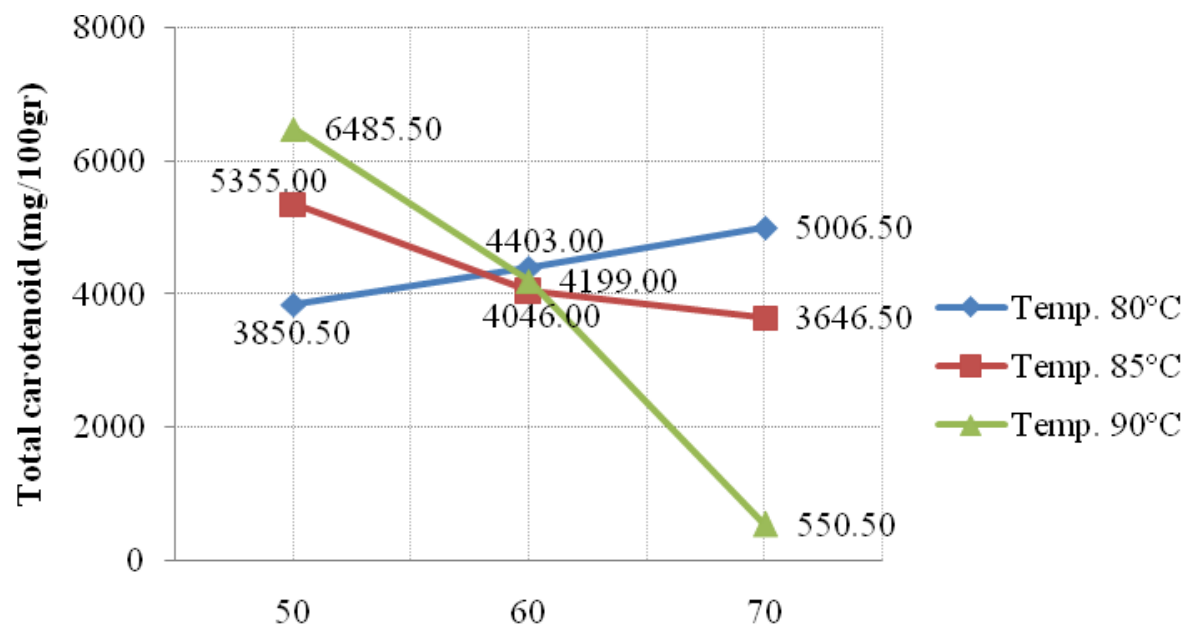

Frying Time (minutes)

Figure 4:- Effect of frying time and temperature on the total carotenoid content of carrot chips

The total carotenoids compounds are precursors of vitamin A. however, both were found in different places in nature. Vitamin A is found in liver, butter, milk, eggs, and products derived from animal while $\beta$-carotene is found in many vegetables that are yellow and dark green ${ }^{19}$. Vitamin A and B-carotene have properties that are easily degraded either by light or heating. This causes the intensity of the heating temperature is increased, the levels continue to decline. ${ }^{18}$ reported the young beans chips with fried traditional vacuum, showed a higher total carotenoid $(66.61 \mu \mathrm{g} / \mathrm{g} \mathrm{db})$ than traditional fried $(54.63 \mu \mathrm{g} / \mathrm{g} \mathrm{db})$. This value is much lower than the levels of $\beta$ carotene on the results of this study. This is understandable because the temperature vacuum frying is done in these studies is very high, namely $90^{\circ} \mathrm{C}$. Besides total carotene is one of the fundamental as precursors of vitamin A that the number would be smaller.

\section{Conclusions:-}

The characteristics (crude fiber, vitamin $\mathrm{C}$, free fatty acid and total carotenoids content) of carrot chips using vacuum frying machine at different frying temperature and frying time were investigated in this research. the optimum frying temperature is $90^{\circ} \mathrm{C}$ and optimum frying time is 50 minutes (A3B1 treatment) which a value of $15.66 \%$ crude fiber content, vitamin C $0.19 \%$, free fatty acid (FFA) $3.91 \%$ and total carotenoids $6485.50 \mathrm{mg} / 100 \mathrm{~g}$.

\section{Acknowledgement:-}

The author gratefully acknowledge to Fateta Unand who financially supported through DIPA Fateta scheme-2015.

\section{References:-}

1. Hambali EMZ, Nasution, Herliana E. Make a Variety of Herbal Tea. Penebar Swadaya, Jakarta, 2005.

2. Ali, Nur Berlian Venus, Estu Rahayu, Hendro Sunarjono. Carrots. Jakarta: Penebar Swadaya, 2003.

3. Sulistyowati A. Making Fruits and Vegetables Chips. ${ }^{\text {st }}$ ed, Puspa Swara, Jakarta, 1999.

4. Garayo J, Moreira RG. Vacuum frying of potato chips. J. of Food Processing Engineering 2002; 55 (2): 181191.

5. Shyu S, HauL, Hwang LS. Effect of Vacuum Frying on the Oxidative Stability of Oils. Journal of the American Oil Chemists Society 1998; 75: 1393-1398.

6. Kawas ML, Moreira RG. Characterization of Product Quality Attributes of Tortilla Chips during the Frying Process. Journal of Food Engineering 2000; 47(2): 97-107.

7. Lujan-Acosta FJ, Moreira RG. (1996). Relationship between Tortilla Chips Microstructure and Oil Reduction. Cereal Chemistry Journal 1996; 74(3): 216-223.

8. Xiong X, Narsimhan G, Okos MR. 1991. Effect of Composition and Pore Structure on Blinding Energy and Effective Diffusivity of Moisture in Porous Food. Journal of Food Engineering 1991; 15(3): 187-208.

9. Crapiste GH, Rotstein E, Whitaker S. Drying Cellular Material. Mass Transfer Theory. Chem. Eng. Sci 1998; 43: 2919-2928. 
10. Achanta S, Okos MR, Cushman JH, Kessler DP. Moisture Transport in Shrinking Gels during Saturated Drying. Journal of Colloid and Interface Science 1995; 169: 58-68.

11. Yenrina R, Yuliana, Rasymida D. Methods of Food Analysis. Universitas Andalas Press, Padang, 2011.

12. AOAC. Official Methods of Analysis. Association of Official Analytical Chemists. Benjamin Franklin Station, Washington, 2005.

13. Apriyantono A, Fardiaz D, Puspitasari NL, Sedamawati, Budiyanto S. Food Analysis. PAU Pangan dan Gizi, IPB, Bogor, 1989.

14. Winarno, FG. Food Chemistry and Nutrition. PT Gramedia Pustaka Utama, Jakarta, 2004.

15. Morello JS, Maria JM, Maria JT, Maria PR. Changes in Commercial Virgin Olive Oil during Storage with Special Emphasis on the Phenolic Fraction. J. of Food Chemistry 2004; 85: 357-364.

16. SNI. Indonesia National Standard. Quality Standard of Extrudate Foods. SNI 01-2886-2000.

17. Tarmizi AHA, Niranjan K, Gordon M. Physicochemical Changes Occurring in Oil when Atmospheric Frying is Combined with Post-Frying Vacuum Application. Food Chemistry 2013; 136: 902-908.

18. Da Silva, Paulo, Moreira RG. Vacuum Frying of High Quality Fruit and Vegetable-based Snacks. LWT-Food Science and Technology 2008; 41: 1758-1767.

19. Mutia N, Hartini TNS, Hakim M. Less intake of vitamin A, C, E and beta-carotene increased the incidence of preeclampsia in Sardjito hospital Yogyakarta. Gizi Indonesia 2010; 33(2): 136-142. 